\title{
Ecological Studies of Symbiosis in Convoluta roscoffensis
}

\author{
S. A. Doonan and G. W. Gooday \\ Department of Microbiology, University of Aberdeen, Aberdeen AB9 1AS, United Kingdom
}

\begin{abstract}
The size of the Convoluta roscoffensis population on a beach in Herm, Channel Islands is subject to wide seasonal variation, being very low in early summer and high in autumn and winter. Of the ecological factors measured, only light - expressed as photosynthetically active radiation - showed a correlation with population size. Low worm numbers, and also low numbers of algae and chlorophyll a content per worm, were associated with high light intensities, and vice versa. Worm spacing within colonies, however, remained relatively constant, with a mean value of $9 \times 10^{5}$ worms $\mathrm{m}^{-2}$. Estimates of photosynthetic cover (chlorophyll biomass) of $320 \mathrm{mg}$ chlorophyll a $\mathrm{m}^{-2}$, and annual primary productivity for 1977 , of $832.9 \mathrm{~g}$ carbon fixed $\mathrm{m}^{-2}$ of colony, approach estimates for coral reefs; they were remarkably high for the potentially disturbed environment of the intertidal sandy beach.
\end{abstract}

\section{INTRODUCTION}

The intertidal flatworm Convoluta roscoffensis Graff is symbiotic with the unicellular green alga Platymonas convolutae Parke et Manton. Adult worms do not ingest food, and this algal-animal association can grow completely autotrophically in the light in seawater containing nitrate and phosphate (Holligan and Gooday, 1975). Each worm is 2 to $4 \mathrm{~mm}$ long and contains 2 to $7 \times 10^{4}$ endosymbiotic algal cells (Doonan, 1979). Colonies of C. roscoffensis are found on sandy beaches, mainly in north-west France and the Channel Islands (Keeble, 1910). When the tide goes out, the worms emerge from beneath the sand to lie in rivulets of beach run-off water; exposure to sunlight allows their algae to photosynthesise.

Most of our knowledge of Convoluta roscoffensis comes from laboratory observations concerned with cytological and biochemical aspects of symbiosis; published field studies (Gamble and Keeble, 1903; Keeble and Gamble, 1907; Guérin, 1960; Fraenkel, 1961) have been largely descriptive. Here we present the results of a quantitative study of $C$. roscoffensis in its natural. habitat over an extended period of time. The study was made in order to assess the relative productivity and dynamics of this symbiotic system: what is the importance of the symbiosis to the ecology of the partners involved, and how does the resulting productivity compare with that of non-symbiotic systems? Summaries of some of our results have been presented by Gooday and Doonan (1980).

\section{MATERIALS AND METHODS}

We have studied Shell Beach, Herm, Channel Islands with its large, conspicuous population of Convoluta roscoffensis. The beach was uniform and sandy, making core-sampling easier than on a pebble beach. Within the study site, an area of $20 \mathrm{~m}$ by $20 \mathrm{~m}$ was chosen in which seasonal changes in the C. roscoffensis population could be measured. The site was visited 6 times, from September 1976 to May 1978. The beach profile was measured according to the method of Emery (1961), and an analysis of sand particle size was carried out in the $20 \mathrm{~m} \times 20 \mathrm{~m}$ grid. To determine levels of dissolved nutrients in the beach run-off water, samples from above and below colonies of $C$. roscoffensis were collected and immediately vacuum filtered through a Millipore Sterifil System, using Millipore filters (pore size $0.45 \mu \mathrm{m}$ ). Samples intended for nitrate, total nitrogen and total phosphorus analysis were poured into polythene bottles and frozen immediately in dry ice. Samples intended for inorganic phosphate analysis were poured into glass bottles containing a few ml of chloroform, and kept cool in subdued light. All samples were analysed within $1 \mathrm{wk}$ of collection, at the Plymouth Laboratory of the Marine Biological 
Association of the U.K. Salinity was measured by the method of Harvey (1955); $\mathrm{pH}$ was recorded in situ using a portable $\mathrm{pH}$ meter.

Inorganic phosphate content was determined as described in Strickland and Parsons (1972); total soluble phosphorus, by the same method on samples irradiated overnight with ultraviolet light (Hanovia Lamp, UVS 500) according to Armstrong and Tibbits (1968). Levels of nitrate were measured by the method of Wood et al. (1967); total nitrogen, by the same method on u.v. irradiated samples.

Instantaneous measurements of incident light in the field were made with a Weston Euro-Master exposure meter calibrated against a Lambda LI-190SR Quantum Sensor ( $T$ \& J. Crump, Wickford, U.K.). Between visits to Herm incident light was computed from data collected at the meteorological station at Jersey Airport, and converted (multiplication by 0.5 ) to PAR (photosynthetically active radiation). By using values of mean daily PAR and daily lengths of tidal exposure for 1977 (Doonan, 1979) it was possible to calculate the portion of total PAR available to Convoluta roscoffensis when exposed by the tide.

To estimate their primary productivity, the amount of carbon fixed by the photosynthetic activity of the symbiotic algae inside Convoluta roscoffensis was measured, at the Plymouth Laboratory, by adapting the ${ }^{14} \mathrm{C}$ method (Strickland and Parsons, 1972), i.e. by treating the worms as 'units of phytoplankton'. Measurements were made within $5 \mathrm{~d}$ of collection. During this time the worms were maintained in ambient conditions, with frequent changes of seawater, and no alterations in algae or animals were observed. The method, described in detail by Doonan (1979), involved incubating groups of 20 worms ( 3 to $4 \mathrm{~mm}$ in length) in Pyrex vials of $32.5 \mathrm{ml}$ of seawater or Herm beach runoff water containing about $5 \mu \mathrm{Ci}$ of $\mathrm{NaH}^{14} \mathrm{CO}_{3}$ (Amersham) at ambient temperature. The vials were exposed to a range of light intensities (dark, 10\%, 30\%, 50\%, $75 \%$ and $100 \%$ transmission; achieved by means of filters) for 3 to $4 \mathrm{~h}$, during which time incident light was measured with a Lambda LI-192S Quantum Sensor attached to a chart recorder. Radioactivity of the samples was measured by liquid scintillation counting. Primary productivity was calculated as $\mu \mathrm{g}$ carbon fixed worm $^{-1}$ and also as $\mathrm{mg}$ carbon fixed (mg chlorophyll a) ${ }^{-1} \mathrm{~h}^{-1}$ at light saturation, i.e. assimilation number, which required extraction of chlorophyll a from the algae inside C. roscoffensis. Groups of 10 worms were placed in $1 \mathrm{ml} 90 \%$ acetone; extinctions of the extracts at $630 \mathrm{~nm}, 645 \mathrm{~nm}$ and $665 \mathrm{~nm}$ were measured, and chlorophyll contents calculated (Strickland and Parsons, 1972).

We determined population density both as number of worms per area of beach and as number per area of worm colony. The former method involved random sampling from the $20 \mathrm{~m}$ by $20 \mathrm{~m}$ grid; the latter, sampling from colonies which were then photographed so that their area could be calculated. In both cases, $5 \mathrm{~cm}$ cores of sand and worms were taken with a Perspex corer (internal diameter $2.5 \mathrm{~cm}$ ). Sampling of the grid involved dividing it into 100 numbered $2 \mathrm{~m}$ squares, and sampling each of these at coordinates (measured in $\mathrm{cm}$ ) chosen from random number tables. Methods of separation and counting of worms are described by Doonan (1979).

Estimations of the number of algae inside Convoluta roscoffensis were made, and the values used in context both of seasonal changes in algal numbers and of photosynthetic rate in relation to body length and algal numbers. Platymonas convolutae were released from their hosts for counting as follows: 25 worms of similar length were placed into a $3 \mathrm{ml}$ Teflon homogeniser and washed several times with filtered seawater. All the seawater was pipetted off and $0.75 \mathrm{ml}$ of filtered seawater added. The worms were gently homogenised by hand to give a uniformly green suspension (10 to $15 \mathrm{~s}$ ). Counts of algae were made on a haemocytometer. This technique was the most reproducible of several tried (e.g. digestion with trypsin, bubbling with $\mathrm{CO}_{2}$ ), giving the most uniform disruption of the worms with the least disruption of the released algae. The reliability of the method can be gauged by the standard deviations in Table 3.

\section{RESULTS}

In the study area, Convoluta roscoffensis occurred about midway between mean high water and mean low water of neap tide, at approximately the point at which the angle of the beach changed (Fig. 1). About $10 \mathrm{~m}$ up the beach from this point, the beach run-off water emerged. The sand was chiefly weathered granite and shell fragments. It was coarse on the landward edge of the sampling grid with about $90 \%$ of particles between 1 and $3 \mathrm{~mm}$ in diameter, and fine at the seaward edge where about $60 \%$ of particles were less than $0.3 \mathrm{~mm}$ in diameter. The temperature of the beach run-off water (and the corresponding sea and air temperatures) showed a two-fold seasonal variation, but solar energy, expressed as mean daily PAR, exhibited a larger fluctuation (Table 1). It was calculated that in 1977 the total PAR on the study area was $7,821 \mathrm{E} \mathrm{m}^{-2}$, and that $C$. roscoffensis was exposed to $4,883 \mathrm{E} \mathrm{m}^{-2}$ of this total.

The beach run-off water was relatively rich in nitrogen and phosphorus (Table 1). The nitrogen was chiefly as nitrate, accounting for $54 \%$ of the total nitrogen in comparison to $40 \%, 3 \%$ and $3 \%$ for 
Fig. 1. Profile of beach study area and site and population densities of Convoluta roscorfensis. Circles: height; squares: worm densities on beach, September 1977; March 1978; $\Delta$ May 1978. 1 Mean high water spring; 2 mean high water neap; 3 site of run-off emergence; 4 site of sampling grid; 5 mean low water neap; 6 mean low water spring

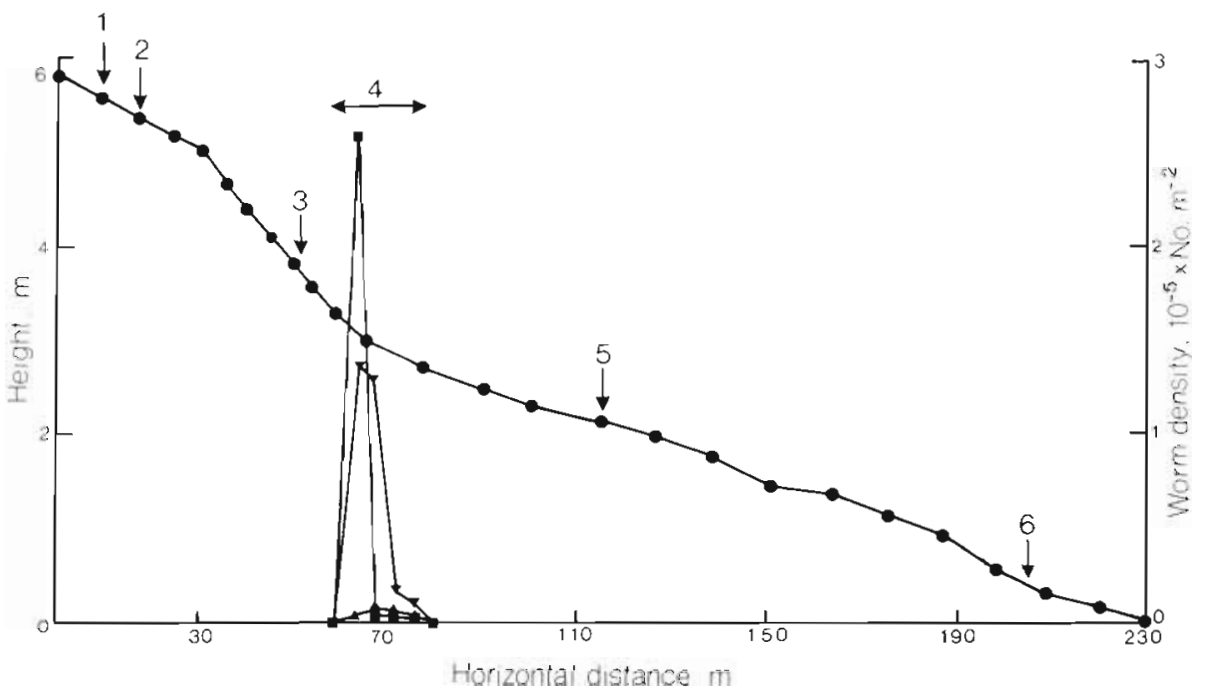

organic nitrogen, ammonia, and urea respectively (average values for 5 samples at each of the collections). The phosphorus was chiefly present as inorganic phosphate, accounting for $90 \%$ of the total phosphorus. Nitrate revealed the most distinct seasonal variation; it was higher in summer. In contrast to Holligan and Gooday (1975), these studies showed no systematic differences in nutrient levels in water samples collected above and below colonies during single periods of tidal exposure. Salinity and $\mathrm{pH}$ values of these samples, averaging at $34.8 \% \mathrm{~S}$ and 7.5 respectively, were close to those of seawater, indicating that this run-off water was seawater from the previous high tide.

The population size of Convoluta roscoffensis in the study grid showed a wide seasonal variation, being very low in early summer and high in autumn and winter (Table 1, Fig. 1). This variation was reflected in the size of colonies rather than the density of animals within an individual colony (i.e. 'worm-spacing') which remained relatively constant (Table 1 ) with a mean value of $9.0 \pm 1.6 \times 10^{5}$ worms $\mathrm{m}^{-2}$ (a total of 65 estimations over the period of study). Biomass, expressed as g chlorophyll a $\mathrm{m}^{-2}$ of colony, however, did show a pattern of fluctuation similar to that of population size with low summer values (Table 1). Since worm density varied little, this fluctuation was the result of changes in chlorophyll a content per worm; more detailed measurements indicated that both algal numbers per worm, and chlorophyll a content per alga were higher in autumn and winter than in summer (Gooday and Doonan, 1980).

Photosynthetic carbon fixation rates were measured for worms 3 to $4 \mathrm{~mm}$ long collected at different times; they varied little in relation to the amount of light energy received. For example, at $1.0 \mathrm{E} \mathrm{m}^{-2}$, fixation ranged between 1.1 and $1.7 \mu \mathrm{g} \mathrm{C}$ worm ${ }^{-1}$, over a temperature range of $10^{\circ}$ to $22^{\circ}$ (Table 2 ).

In June 1977, measurements made at light of up to $20 \mathrm{E} \mathrm{m}^{-2}$ revealed above about $10 \mathrm{Em}^{-2}$ a rapid decrease in carbon fixation (i.e. photoinhibition occurred) giving, for example, a value of $0.34 \pm 0.12 \mu \mathrm{g} \mathrm{C}$ fixed worm ${ }^{-1}$ at $19 \mathrm{E} \mathrm{m}^{-2}\left(19^{\circ}\right)$.

In most experiments, light saturation occurred

Table 1. Convoluta roscoffensis. Seasonal variation in enviromental factors and the population on Herm, Channel Islands

\begin{tabular}{|c|c|c|c|c|c|c|}
\hline \multirow[t]{3}{*}{ Factor } & \multicolumn{6}{|c|}{ Date } \\
\hline & \multirow{2}{*}{$\begin{array}{c}1976 \\
\text { Sep }\end{array}$} & \multicolumn{3}{|c|}{1977} & \multicolumn{2}{|c|}{1978} \\
\hline & & Feb & May & Sep & Mar & May \\
\hline Mean run-off temp. $\left({ }^{\circ} \mathrm{C}\right)$ & $16.3 \pm 1.4$ & $9.3 \pm 1.0$ & $16.5 \pm 3.0$ & $17.0 \pm 1.7$ & $9.2 \pm 2.2$ & $13.2 \pm 1.8$ \\
\hline Mean daily PAR $\left(\mathrm{E} \mathrm{m}^{-2}\right)$ & 18.0 & 11.0 & 54.0 & 14.0 & 18.0 & 42.0 \\
\hline Total nitrogen in run-off water ( $\mu$ g atoms $\mathrm{N} \mathrm{I}^{-1}$ ) & $12.0 \pm 2.6$ & $16.0 \pm 1.6$ & $8.6 \pm 0.2$ & $14.3 \pm 1.8$ & $34.8 \pm 8.1$ & $14.6 \pm 5.0$ \\
\hline Total phosphorus in run-off water ( $\mu \mathrm{g}$ atoms $\mathrm{P}^{-1}$ ) & $0.8 \pm 0.1$ & $0.4 \pm 0$ & $0.5 \pm 0.1$ & $0.8 \pm 0.1$ & $0.8 \pm 0.2$ & $0.9 \pm 0.1$ \\
\hline Density: $10^{-3} \times$ No. worms $\mathrm{m}^{-2}$ on beach & N.D. & 182.8 & 4.6 & 256.1 & 121.1 & 1.7 \\
\hline $10^{-5} \times$ No. worms $\mathrm{m}^{-2}$ of colony & $11.1 \pm 2.6$ & $8.5 \pm 2.0$ & N.D. & $10.8 \pm 1.8$ & $8.5 \pm 2.5$ & $7.5 \pm 1.9$ \\
\hline Biomass in colony (g chlorophyll $a \mathrm{~m}^{-2}$ ) & $0.25 \pm 0.05$ & $0.25 \pm 0.06$ & N.D. & $0.32 \pm 0.05$ & $0.17 \pm 0.05$ & $0.09 \pm 0.02$ \\
\hline
\end{tabular}

Values, except for PAR and worm density, quoted with standard deviations $(n=5)$ 
Table 2. Convoluta roscoffensis. Primary productivity of worms with body length of 3 to $4 \mathrm{~mm}$

\begin{tabular}{|c|c|c|c|c|c|c|}
\hline & \multirow{2}{*}{$\begin{array}{c}1976 \\
22 \text { Sep }\end{array}$} & \multicolumn{3}{|c|}{1977} & \multicolumn{2}{|c|}{1978} \\
\hline & & $8 \mathrm{Feb}$ & $8 \mathrm{Jun}$ & 5 Oct & 9 Mar & 1 Jun \\
\hline$\mu g \mathrm{C}$ fixed worm ${ }^{-1}$ at $1 \mathrm{E} \mathrm{m}^{-2}$ & 1.1 & 1.1 & 1.2 & 1.4 & 1.5 & 1.2 \\
\hline Max. photosynthetic rate $\left(\mu \mathrm{g} \mathrm{C}\right.$ worm $\left.{ }^{-1} \mathrm{~h}^{-1}\right)$ & 0.66 & 0.45 & 0.28 & 0.33 & 0.49 & 0.40 \\
\hline Assimilation No. (mg C [mg chl. $a]^{-1} \mathrm{~h}^{-1}$ ) & 2.9 & N.D. & 2.8 & 1.1 & 2.5 & N.D. \\
\hline Temperature $\left({ }^{\circ} \mathrm{C}\right)$ & 22 & 11 & 18 & 14 & 13 & 18 \\
\hline
\end{tabular}

Table 3. Convoluta roscoffensis. Photosynthetic rate in relation to body length and algal numbers

\begin{tabular}{|c|c|c|c|c|}
\hline Date & $\begin{array}{l}\text { Body length } \\
\quad(\mathrm{mm})\end{array}$ & $\begin{array}{l}10^{-3} \times \text { mean no. } \\
\text { algae worm }{ }^{-1}(n=15)\end{array}$ & $\begin{array}{c}\text { Ratio } \\
\text { algal no. in } 3-4 \mathrm{~mm} \\
\text { algal no. in } 2-3 \mathrm{~mm}\end{array}$ & $\begin{array}{c}\text { Ratio } \\
\frac{C \text { fixation in } 3-4 \mathrm{~mm}}{\text { C fixation in } 2-3 \mathrm{~mm}}\end{array}$ \\
\hline 05.10 .77 & $\begin{array}{l}3-4 \\
2-3\end{array}$ & $\begin{array}{l}69.9 \pm 5.4 \\
51.0 \pm 9.2\end{array}$ & 1.37 & 1.54 \\
\hline 10.03 .78 & $\begin{array}{l}3-4 \\
2-3\end{array}$ & $\begin{array}{l}44.3 \pm 7.5 \\
30.9 \pm 3.1\end{array}$ & 1.43 & 1.25 \\
\hline
\end{tabular}

between 1 and $2 \mathrm{Em}^{-2}$; the mean maximum photosynthetic rate ranged from 0.21 to $0.96 \mu \mathrm{g} \mathrm{C}$ worm $^{-1}$ $\mathrm{h}^{-1}$, giving assimilation numbers from 1.1 to $3.0 \mathrm{mg} \mathrm{C}$ (mg chlorophyll a) ${ }^{-1} \mathrm{~h}^{-1}$ (Table 2). Fixation of carbon in the dark was very low, so that at saturating light levels fixation in the light ranged from 73 to 518 times that in the dark.

Worms with body length of 3 to $4 \mathrm{~mm}$ contained about 1.4 times as many algae as worms 2 to $3 \mathrm{~mm}$ long, and fixed a correspondingly greater amount of carbon over the same period of time (Table 3 ).

An estimate of annual primary production of Convoluta roscoffensis for 1977 was made using values of daily carbon fixation per worm and worm density in the field at different seasons. The value for carbon fixed was $872.9 \mathrm{~g} \mathrm{~m}^{-2}$ of colony.

\section{DISCUSSION}

Light was the only environmental factor that correlated with seasonal fluctuations in the Convoluta roscoffensis population, i.e. numbers of worms, numbers of algae and, less marked, chlorophyll a content per worm. Low worm numbers, low algal numbers and low chlorophyll levels were associated with high light intensities. Light (PAR) and worm density on the beach were negatively correlated with a coefficient of 0.90 . The chlorophyll content of many algae is inversely proportional to the amount of light received during growth (Meeks, 1974), and the symbiotic algae Chlorella sp. inside Hydra viridis have been observed to bleach under high light intensity (Pardy, 1976). Pardy suggests that decreases in algal chlorophyll levels may be the result of both a cell-regulated process and a process of photo-destruction.

Three aspects in the behaviour of Convoluta roscoffensis likely to affect light utilization for photosynthesis are (1) rapid secretion of mucus, which Fraenkel (1961) suggests might allow the worms to float above the sand and so be exposed to light reflected from the sand; (2) burrowing back down into the sand after a few hours in bright sunshine (perhaps to avoid photoinhibition?); and (3) continual motion, which must affect shading each other. An estimate, made using photographs, of the area of an adult worm as viewed from above was $0.50 \pm 0.06 \mathrm{~mm}^{2}$ (14 measurements). This gives mean values of \% cover of worms on the sand in colonies of 34 to 56 (using values in Table 1). Thus, although there is sufficient space for all worms to be fully exposed to the light, they move ceaselessly, and hence shade each other to some extent.

The photosynthetic cover (chlorophyll biomass) of colonies of Convoluta roscoffensis, of up to $320 \mathrm{mg}$ chlorophyll $a \mathrm{~m}^{-2}$, is similar to that of coral reefs, or of epipsammic foraminiferans with algal symbionts, and of an intertidal epilithic community of algae (reviewed by Raven, 1981). The highest theoretical value for freeliving phytoplankton in the euphotic zone is $200-300$ mg chlorophyll $\mathrm{am}^{-2}$ (Talling et al., 1973), while Anderson (1967) suggests that the maximum useable chlorophyll cover in natural communities is $600 \mathrm{mg} \mathrm{m}^{-2}$. Raven (1981) concludes that photosynthetic cover is usually higher in less disturbed environments. The intertidal zone can be a very disturbed environment, but for $C$. roscoffensis, motility overcomes this by re-establishing the temporary stability of the colony between each tide. 
Comparison of the value of annual primary production of Convoluta roscoffensis of close to $1 \mathrm{~kg} \mathrm{C} \mathrm{m}^{-2}$ with other photosynthetic systems shows that it is higher than values for phytoplankton, approaching values for coral reefs (Ryther, 1969; Taylor, 1973; Gooday and Doonan, 1980; Muscatine, 1981). This is a remarkable achievement for organisms living in such a potentially disturbed environment as is an intertidal sandy beach. Assimilation numbers of $1.1-3.0 \mathrm{mg} \mathrm{C}$ (mg chlorophyll a) ( $^{-1} \mathrm{~h}^{-1}$ for $\mathrm{C}$. roscoffensis are similar to values found for free-living plankton and for algae on a sandy beach (reviewed by Raven et al., 1979; Gooday and Doonan, 1980). The annual primary production of the symbiotic algae inside C. roscoffensis is higher than values for free-living phytoplankton (Gooday and Doonan, 1980; reviewed by Muscatine, 1981)

These high levels of photosynthetic activity in Convoluta roscoffensis may be attributed to: (1) its gregarious habit and ability to re-form colonies after disruption by the tide; (2) the dense packing of algal symbionts inside the worm (estimated density $10^{8}$ algae cells $\mathrm{ml}^{-1}$ of host tissue, assuming values of $4 \times 10^{4}$ algae in a worm volume of $0.4 \mu \mathrm{l}$ ); and (3) the intimate cellular interrelationships which allow algae to be maintained within the host in peak photosynthetic condition, while exporting a large proportion (37-58\%; Smith, 1978) of their photosynthate to the animal tissue.

Acknowledgements. We thank Dr. P. M. Holligan and his colleagues at the Plymouth Laboratory for help with the analyses, and Mr. R. E. Thebault of Jersey Airport for meteorological data.

\section{LITERATURE CITED}

Anderson, M. C. (1967). Photon flux, chlorophyll content and photosynthesis under natural conditions. Ecology 48: 1050-1053

Armstrong, F. A. J., Tibbitts, S. (1968). Photochemical combustion of organic matter in seawater for nitrogen, phosphorus and carbon determination. J. mar biol. Ass. U.K. 48: $143-152$

Doonan, S. A. (1979). Ecological studies of symbiosis in Convoluta roscoffensis. $\mathrm{Ph}$. D. thesis, University of Aberdeen

Emery, K. O. (1961). A simple method of measuring beach profiles. Limnol. Oceanogr. 6: 90-93

Fraenkel, G. (1961). Quelques observations sur le comporte- ment de Convoluta roscoffensis. Cah. Biol. Mar. 2: 155-160

Gamble, F. W. Keeble, F. (1903). The bionomics of Convoluta roscoffensis, with special reference to its green cells. Quart. J. microsc. Sci. 47.364-431

Gooday, G. W. Doonan, S. A. (1980). The ecology of algalinvertebrate symbioses. In: Ellwood, D. C., Hedger, J. N., Latham, M. J., Lynch, J. M., Slater. J. H. (eds.) Contemporary microbial ecology. Academic Press, London, pp. $377-309$

Guérin, M. (1960). Observations ecologiques sur le Convoluta roscoffensis Graf. Cah. Biol. Mar 1: 205-220

Harvey, H. W (1955). The chemistry and fertility of sea waters, Cambridge University Press, Cambridge

Holligan, P. M., Gooday, G. W. (1975). Symbiosis in Convoluta roscoffensis. In: Jennings, D. H., Lee, D. L. (eds.) Symbiosis, Symp. Soc. Exp. Biol., Vol. 29. Cambridge University Press, Cambridge, pp. 205-227

Keeble, F. (1910). Plant-animals: a study in symbiosis, Cambridge University Press, Cambridge

Keeble, F., Gamble, F. W. (1907). The origin and nature of the green cells of Convoluta roscoffensis. Quart. J. microsc. Sci. 51: 167-219

Meeks, J. C. (1974). Chlorophylls. In: Stewart, W. D. P. (ed.) Algal physiology and biochemistry, Bot. Monographs, Vol. 10. Blackwell, Oxford, pp. 161-175

Muscatine, L. (1981). Productivity of zooxanthellae. In: Falkowski, P. G. (ed.) Primary productivity in the sea. Plenum Press, New York, pp. 381-402

Pardy, R. L. (1976). The production of a posymbiotic hydra by the photodestruction of green hydra zoochlorellae. Biol. Bull. mar biol. Lab., Woods Hole 154: 565-579

Raven, J. (1981). Nutritional studies of submerged benthic plants: acquisition of carbon, nitrogen and phosphorus by haptophytes and rhizophytes. New Phytol. 88: 1-30

Raven, J., Smith, F. A., Glidewell, S. M. (1979). Photosynthetic capacities and biological strategies of giant-celled and small-celled macro-algae. New Phytol. 83: 299-309

Ryther, J. H. (1969). Photosynthesis and fish production in the sea. Science, N.Y. 166: 72-76

Smith, D. C. (1978). Photosynthetic endosymbionts of invertebrates. In: Bull, A. T., Meadow, P. M. (eds.) Companion to microbiology. Longmans, London, pp. 387-414

Strickland, J. D. H., Parsons, T. R. (1972). A practical handbook of seawater analysis, 2nd ed. Fish. Res. Bd Can., Ottawa Bull. 167

Talling, J. F., Wood, R. B., Prosser, M. V., Baxter, R. M. (1973). The upper limit of photosynthetic productivity by phytoplankton: evidence from Ethiopian soda lakes. Freshwat. Biol. 3: 53-76

Taylor, D. L. (1973). Symbiotic pathways of carbon in coral reef ecosystems. Helgoländer wiss. Meeresunters. 24: $276-283$

Wood, E. D., Armstrong, F. A. J., Richards, F. A. (1967). Determination of nitrate in seawater by cadmium-copper reduction to nitrite. J. mar. biol. Ass. U.K. 47: 23-31 